\title{
Analysis of Transportation Network Design with Time Window Delivery and Milk Run Method
}

\author{
Niche Evandani ${ }^{1, *}$ Nofrisel $^{2}$
}

\author{
${ }^{1}$ Universitas Indonesia \\ ${ }^{2}$ Universitas Indonesia \\ ${ }^{*}$ Corresponding author. Email: niche.evandani@gmail.com
}

\begin{abstract}
The flavor business has a high complexity because the materials are unique and specific for most customers. Many variables affecting the shipping cost become a challenge for PT XYZ as one of Flavor House in Indonesia. Thus, it is important for PT XYZ to conduct further analysis of the transportation network design with Time Window Delivery and Milk Run method in order to improve operational cost efficiency. Determination of the Milk Run route is based on the customer cluster area and the Clarke-Wright Algorithm principle. In the results of the study, it was found that $76 \%$ of customers had higher fleet rental per unit of goods (KG) than distributors who applied the window time method. The simulation results of shipment with time window method can reduce the trucking cost, while the simulation milk run route in 6 area delivery can reduce the length of trip with total $3346 \mathrm{KM}$.
\end{abstract}

Keywords: transportation network design, time window delivery, milk run method.

\section{INTRODUCTION}

Inaccurate delivery schedule can be a source of waste in the supply chain concept due to excessive expenditure. Delivery which is too early than target contributes to excess inventory storage costs, while late delivery can contribute to the cost of penalties from customers [1]. In addition to penalty fees, additional costs can also be incurred such as costs to speed up the process, potential loss of sales, or a decrease in the company's reputation. According to Bushuev [2], one of strategies to improve delivery performance is to reduce variations in shipping.

Purchase Orders (PO) provided by customers mostly do not have a clear pattern, so it is important for supply chain customer service to be proactive in managing delivery schedules such as consolidating. Consolidation of shipments can increase the efficiency of shipping costs and improve service performance for customers because it indirectly helps arrange the schedule for receiving goods on the customer side. One form of strategy for design transportation network is a delivery time window, where grouping and merging are carried out to customers who have the same destination area.

PT XYZ is one of the Flavor Houses in Indonesia. The distribution area of flavor products from PT XYZ has included domestic shipments (coverage of the island area of Java) and abroad (coverage of Asian exports). The distribution of flavor products from PT XYZ is mostly aimed at Industrial areas in JABABEKA, as well as Central and East Java. A large number of variables that affects the cost of shipping products is a challenge for PT XYZ. This is also influenced by product type, volume, shipping area, and ordering the frequency of the customer. During this time, PT XYZ implemented shipments to customers using the direct shipment method. Therefore, it is important for PT XYZ to conduct further analysis of the distribution network matrix design to improve operational cost efficiency.

Flavor is an ingredient which gives aroma and taste to food and beverages. This kind of materials is produced from raw materials that have met BPOM standards and food grade category. The Flavor House business transaction is conducted with other food manufacturing companies, hence it is categorized into the B2B (Business to Business) business category.

The finished goods of flavor house generally have a shelf life within six months-18 months. However, the majority of customers have a minimum provision for product shelf life when supplying goods (the minimum remaining product life is $50-75 \%$ when shipping to customers). This requirement and short shelf life of the 
product made company cannot set a lot of buffer stock in work in process (WIP) or finished goods (FG).

The inventory character of the flavor house industry tends to be expensive, although in terms of volume it is not too much. It is important for the flavor house industry to manage inventory efficiently and follow the principles of lean manufacturing. The concept of lean manufacturing in companies needs to be supported by a lean supply chain, wherein the application of lean supply chain, a good flow of information and product flow are needed between the whole department concerned, both upstream (vendor) and downstream (customer).

At flavor houses, orders from customers are generally inputted into the system by supply chain customer service. During the input process, a targeted delivery schedule has also been set for each order from the customer. The company will also measure operational performance based on how many orders can be delivered on time from the date of the first request (1st requested Good Issued date). Orders whose shipping schedules are recorded backward on the system will be justified as negative performance and need to be given a reason for not fulfilling customer demand. Therefore, placing orders with the appropriate date is a crucial factor for the company.

\section{METHODS}

\subsection{Materials and Procedure}

The data used in this study was secondary data and was divided into three sources as follows:

- Data obtained by downloading company data from PT XYZ, in the form of delivery report data for the period of 2018 .

- Data on the distance from the Distribution Center in Karawang with customer delivery locations via Google Maps.

- Other secondary data obtained through literature studies both from previous research journals, articles, textbooks and related agency reports

In this study, the truck rental cost calculation was carried out on two types of distribution network models at PT XYZ. This research model adapted the research model related to the comparison of just in time and delivery time window that had been done before by [3]

- Model 1: Calculation of truck rental costs from one PT XYZ distributor who has used the delivery time window.

- Model 2: Calculation of truck rental costs based on PT XYZ direct customer shipping data in 2018.
Calculation of truck rental costs per unit $\mathrm{KG}$ refers to the (1)

$\mathrm{TC}=\mathrm{RC} /(\mathrm{ADV} / \mathrm{ADF})$

$$
\begin{array}{ll}
\mathrm{TC} & =\text { Truck rental costs per KG unit (IDR/KG) } \\
\mathrm{RC} & =\text { Truck rental costs per trip } \\
\mathrm{ADV} & =\text { Annual Delivery Volume (KG) } \\
\mathrm{ADF} & =\text { Annual Delivery Frequency }
\end{array}
$$

\subsection{Design Transportation Network}

Transportation network design affects the operational performance of a company. There are several variations in the design of transportation networks that can be used by the company according to the characteristics of the business being run. According to [4], there are two commonly used direct shipment methods, including Direct Shipment Design for Single Destinations and Direct Shipment Design with Milk Run.

Companies can analyze the range of periods that are still included in the customer acceptance schedule with a minimum risk of late delivery [5]. Coordination between suppliers and buyers in implementing the delivery time window has implications for the strategy of improving supply chain performance. Delivery Time Window is one strategy that is widely used by logistics service companies. The central principle is to determine a specific period for the distribution process to a particular location.

The Milk Run method implements a delivery network from one supplier to several customers on a harmonious route [4]. The shipping route starts from the customer with the closest distance first, then continues with other customers. This design can improve the efficiency of shipping costs due to the consolidation process. The Milk Run design is applied appropriately when the volume of shipments in each location is quite small and under optimal load, and there are some customers located in the near area [6].

\subsection{Milk Run Method with Clarke-Wright Algorithm}

In general, the farther the distance between the delivery destination and the distribution center, the greater the shipping cost will be. This vehicle routes problem revolves around the utilization and coordination of transportation resources to meet the company's requirement [7]. Meanwhile, the shipping cost per unit can be minimized by scheduling shipments that meet the concept of economies of scale [8].

Delivery network optimization can be calculated using Clarke-Wright Algorithm. The purpose of this 
method is to minimize the total distance of vehicle trips to accommodate shipments to many customers within one day of delivery. Through the Clarke-Wright method, matrix simulations were conducted to design better routes based on the largest saving value [4]. The value of saving is calculated from the difference in distance between individual shipments and milk run shipments.

Before applying the Milk Run design on the shipping route, customer clustering was conducted first based on the shipping area and the distance from DC PT XYZ. This calculation used shipping data during 2018 for 67 customers with the largest shipment volume. The flowchart for determining distribution lines can be seen in Figure 1.

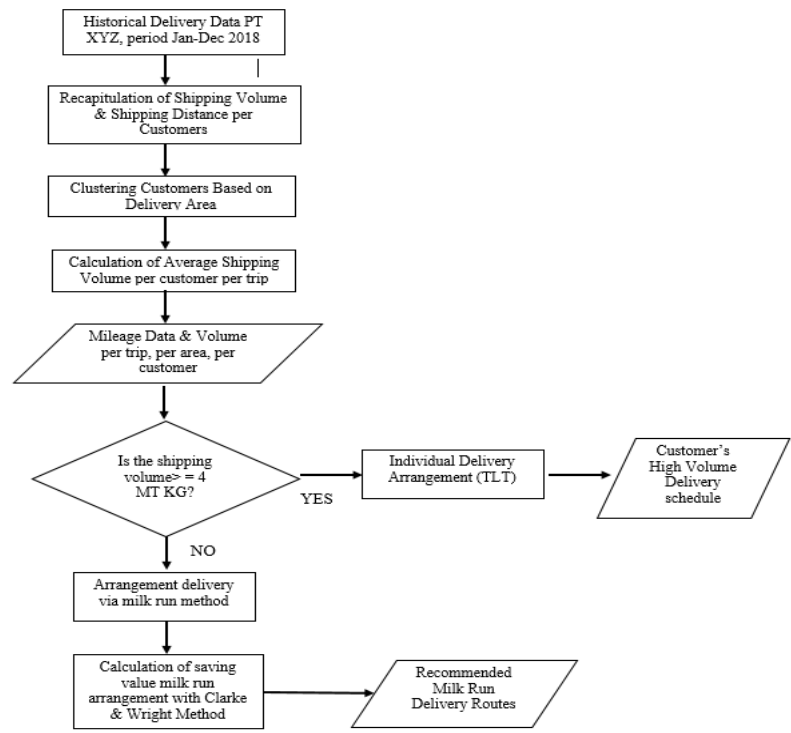

Figure 1. Transportation Path Determination Chart

The Clarke-Wright method uses a fairly simple approach, thus it can be implemented quickly and applicable for many types of industries [9]. This method is widely used for shipping by land transportation such as delivery car and container truck because distance calculation and route selection are more flexible than transportation by air and sea mode. Steps to use the Clarke \& Wright method algorithm in this study are as below.

1. Identify the mileage matrix

2. Identify the saving matrix

Saving matrix $\mathrm{S}(\mathrm{x}, \mathrm{y})$ presents the distance savings obtained if a vehicle visits multiple locations simultaneously compared to visiting one by one the shipping location. The value of saving matrix can be formulated in (2).

$\mathrm{S}(\mathrm{x}, \mathrm{y})=\mathrm{D}(\mathrm{DC}, \mathrm{x})+\mathrm{D}(\mathrm{x}, \mathrm{y})-\mathrm{D}(\mathrm{x}, \mathrm{y})$
Where,

- $\quad \mathrm{S}(\mathrm{x}, \mathrm{y})$ : Value of saving matrix from customer $\mathrm{x}$ to customer $\mathrm{y}$

- $\quad \mathrm{D}(\mathrm{DC}, \mathrm{x})$ : Distance from the factory (distribution center) to customer $\mathrm{x}$

- $\quad$ D (DC.y): Distance from the factory (distribution center) to customer y

- $\quad \mathrm{D}(\mathrm{x}, \mathrm{y})$ : Distance from customer $\mathrm{x}$ to customer $\mathrm{y}$

3. Determine customer router per area based on saving matrix

\section{RESULTS AND DISCUSSION}

In this study, historical delivery data of 67 customers with the largest shipment volume in PT XYZ were analyzed. It is found that the customer's location area are spread most in the West Java Industry (57\%), then followed by the East Java province (16\%). It can be seen that many customers are centered on shipping areas in the areas of Tangerang, Cikarang, Karawang, Semarang, Pasuruan and Surabaya as seen in Figure 2. High delivery volume is intended for customers in Cikampek (1722 MT), followed by customers in Cikarang (1165 MT), Tangerang (1049 MT), Gresik (740 MT) and Pasuruan (521 MT).

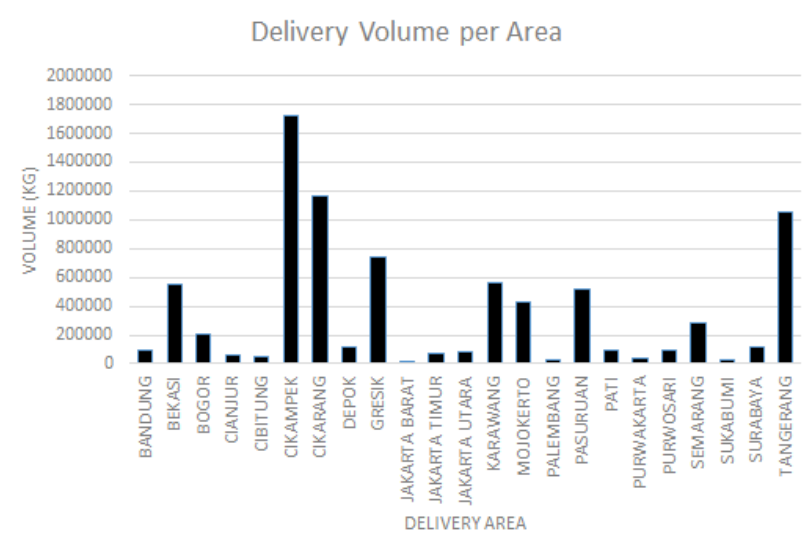

Figure 2. Delivery Volume Distribution per Customer Area

Model 1: Calculation of transporter rental costs from one PT XYZ distributor who has used the delivery time window

As a comparative value of domestic customer shipping cost efficiency, the cost of leasing the fleet per unit (KG) from the distributor of PT XYZ was calculated. This distributor helps serve orders from small customers of PT XYZ in the JABODETABEK area. The collection time is twice a week with window on every Tuesday and Thursday. The result of model analysis can be seen on Table 1 . 
Table 1. Distributor A Data Processing Results

\begin{tabular}{|l|l|}
\hline \multicolumn{1}{|c|}{ Indicator } & \multicolumn{1}{c|}{ Value } \\
\hline Total frequency of shipments in 2018 & 105 times \\
\hline Average collection frequency per week & 2.1 times \\
\hline Average shipment volume per week (KG) & $13868 \mathrm{KG}$ \\
\hline Average shipping volume per trip (KG) & $6604 \mathrm{KG}$ \\
\hline Fleet Rental Cost per trip (IDR) & IDR 900,000.00 \\
\hline Transportation Fleet Rental Costs per KG (IDR) & IDR 136.30 \\
\hline
\end{tabular}

Model 2: Calculation of transporter rental costs based on PT XYZ direct customer shipping data in 2018.

Based on the results of domestic customer data processing, it was known that around $76 \%$ of the total 67 customers had a transportation fleet rental fee per KG (IDR) above 150. Therefore, there is an opportunity in the morning of PT XYZ to increase the efficiency of fleet rental costs by implementing a window time delivery, where it is necessary to aggregate customer shipments in the low density category every week.

In this study a simulation was carried out to see the effect of implementation the time window method using data delivery in 2018. Experiments were carried out by simulating the shipment volume of each customer in one week. Based on the experiment, it is known that there is an increase in the efficiency of truck rental costs for PT $\mathrm{XYZ}$ customers which is characterized by a decrease in truck rental costs per KG unit as in Table 2.

Table 2. Simulation Results for the Application of the Time Window Delivery Method at PT XYZ.

\begin{tabular}{|c|c|c|}
\hline \multirow[b]{2}{*}{$\begin{array}{c}\text { Trucking rental costs } \\
\text { per KG unit }\end{array}$} & \multicolumn{2}{|c|}{ Number of Customers } \\
\hline & $\begin{array}{c}\text { Before Time } \\
\text { Window }\end{array}$ & $\begin{array}{c}\text { After Time } \\
\text { Window }\end{array}$ \\
\hline IDR 0-150 & 16 & 24 \\
\hline IDR $151-300$ & 23 & 17 \\
\hline IDR 301-450 & 9 & 10 \\
\hline IDR 451-600 & 6 & 6 \\
\hline >IDR 601 & 13 & 9 \\
\hline
\end{tabular}

The disadvantage of applying the time window delivery method is that there is an additional storage cost and requires more complex coordination than the direct delivery method of a single destination. However, referring to PT XYZ's strategy that has implemented lean manufacturing, the tradeoff of storage costs should not be too large because the product production schedule has been adjusted to the delivery schedule as a form of minimizing waste time to save goods [10]. The application of time window shipping methods at PT $\mathrm{XYZ}$ is also supported by adequate infrastructure, one of which is SAP as an example of ERP, so that the data information flow is more integrated to facilitate the determination of strategy and decision making. This is in line with the benefits of ERP as explained by [11].
Table 3. Mileage Matrix and Average Volume per Trip per Customer

\begin{tabular}{|c|c|c|c|}
\hline Area & $\begin{array}{c}\text { Code } \\
\text { Customer }\end{array}$ & $\begin{array}{c}\text { Distance } \\
\text { from DC } \\
(\mathrm{KM})\end{array}$ & $\begin{array}{l}\text { Mean Volume } \\
\text { per trip (KG) }\end{array}$ \\
\hline \multirow{2}{*}{ Bandung } & BDG1 & 80 & 1198 \\
\hline & BDG2 & 111 & 1505 \\
\hline \multirow{4}{*}{ Bekasi } & BKS1 & 54 & 299 \\
\hline & BKS2 & 56 & 6134 \\
\hline & BKS3 & 30 & 2016 \\
\hline & BKS4 & 30 & 1287 \\
\hline \multirow{5}{*}{ Bogor } & BGR1 & 60 & 946 \\
\hline & BGR2 & 97 & 408 \\
\hline & BGR3 & 59 & 376 \\
\hline & BGR4 & 63 & 1992 \\
\hline & BGR5 & 106 & 1081 \\
\hline \multirow{2}{*}{ Cianjur } & CJR1 & 103 & 2191 \\
\hline & CJR2 & 103 & 3783 \\
\hline \multirow{2}{*}{ Cibitung } & CBT1 & 33 & 1114 \\
\hline & CBT2 & 38 & 596 \\
\hline \multirow{2}{*}{ Cikampek } & CKP1 & 30 & 8270 \\
\hline & CKP2 & 28 & 321 \\
\hline \multirow{13}{*}{ Cikarang } & CKR1 & 31 & 1444 \\
\hline & CKR2 & 30 & 442 \\
\hline & CKR3 & 27 & 374 \\
\hline & CKR4 & 28 & 1542 \\
\hline & CKR5 & 27 & 538 \\
\hline & CKR6 & 27 & 207 \\
\hline & CKR7 & 30 & 369 \\
\hline & CKR8 & 23 & 371 \\
\hline & CKR9 & 31 & 5164 \\
\hline & CKR10 & 23 & 868 \\
\hline & CKR11 & 29 & 580 \\
\hline & CKR12 & 28 & 4750 \\
\hline & CKR13 & 21 & 474 \\
\hline \multirow{2}{*}{ Depok } & DPK1 & 77 & 3666 \\
\hline & DPK2 & 79 & 825 \\
\hline \multirow{2}{*}{ Gresik } & GSK1 & 749 & 8332 \\
\hline & GSK2 & 749 & 2694 \\
\hline $\begin{array}{l}\text { Jakarta } \\
\text { Barat }\end{array}$ & JKB1 & 74 & 257 \\
\hline \multirow{2}{*}{$\begin{array}{l}\text { Jakarta } \\
\text { Timur }\end{array}$} & JKT1 & 62 & 723 \\
\hline & JKT2 & 69 & 1013 \\
\hline \multirow{2}{*}{$\begin{array}{l}\text { Jakarta } \\
\text { Utara }\end{array}$} & JKU1 & 62 & 515 \\
\hline & JKU2 & 64 & 1072 \\
\hline \multirow{4}{*}{ Karawang } & KRW1 & 22 & 5186 \\
\hline & KRW2 & 12 & 2153 \\
\hline & KRW3 & 22 & 1516 \\
\hline & KRW4 & 2 & 4190 \\
\hline \multirow{2}{*}{ Mojokerto } & MKT1 & 687 & 7156 \\
\hline & MKT2 & 713 & 374 \\
\hline Palembang & PLB1 & 668 & 1209 \\
\hline \multirow{3}{*}{ Pasuruan } & PSR1 & 778 & 1240 \\
\hline & PSR2 & 758 & 12166 \\
\hline & PSR3 & 751 & 5026 \\
\hline Pati & PT1 & 477 & 1324 \\
\hline Purwakrta & PWK1 & 39 & 793 \\
\hline Purwosari & PWS1 & 777 & 2342 \\
\hline \multirow{4}{*}{ Semarang } & SMG1 & 384 & 1140 \\
\hline & SMG2 & 378 & 3834 \\
\hline & SMG3 & 384 & 735 \\
\hline & SMG4 & 405 & 947 \\
\hline Sukabumi & SBM1 & 122 & 844 \\
\hline \multirow{3}{*}{ Surabaya } & SBY1 & 762 & 942 \\
\hline & SBY2 & 723 & 852 \\
\hline & SBY3 & 720 & 2351 \\
\hline & TRG1 & 102 & 250 \\
\hline langgerang & TRG2 & 107 & 3343 \\
\hline
\end{tabular}




\begin{tabular}{|c|l|l|l|}
\hline Area & $\begin{array}{c}\text { Code } \\
\text { Customer }\end{array}$ & $\begin{array}{c}\text { Distance } \\
\text { from DC } \\
\text { (KM) }\end{array}$ & $\begin{array}{c}\text { Mean Volume } \\
\text { per trip (KG) }\end{array}$ \\
\hline \multirow{7}{*}{} & TRG3 & 96 & 490 \\
\cline { 2 - 4 } & TRG4 & 101 & $\mathbf{4 7 0 5}$ \\
\cline { 2 - 4 } & TRG5 & 108 & 493 \\
\cline { 2 - 4 } & TRG6 & 114 & 2288 \\
\cline { 2 - 4 } & TRG7 & 114 & $\mathbf{4 3 7 7}$ \\
\hline
\end{tabular}

After clustering the customer per area as Table 3, there are 12 customers who have met the threshold for individual shipments. The volume threshold used is the average volume of shipments per trip above $4000 \mathrm{KG}$, so that individual shipments can be done with a light fleet of fuso or above. The remaining 55 other customers can be shipped with the Milk Run design, but still need to pay attention to the customer's capacity and time window barriers.

Table 4. Milk Run Delivery Routes

\begin{tabular}{|c|c|c|c|c|c|}
\hline Area & Trip & $\begin{array}{c}\text { Tital } \\
\text { Mileag } \\
\text { e (KM) }\end{array}$ & $\begin{array}{c}\text { Deliver } \\
\text { y } \\
\text { Volume } \\
\text { (KG) }\end{array}$ & $\begin{array}{c}\text { Total } \\
\text { Mileage } \\
\text { of } \\
\text { Individua } \\
\text { I } \\
\text { Shipment } \\
\text { (KM) }\end{array}$ & $\begin{array}{c}\text { Tatal } \\
\text { Saving } \\
\text { Mileag } \\
\text { e (KM) }\end{array}$ \\
\hline $\begin{array}{l}\text { Tangeran } \\
\mathrm{g}\end{array}$ & $\begin{array}{l}\text { DC - } \\
\text { TRG1 } \\
- \\
\text { TRG6 } \\
- \\
\text { TRG5 } \\
- \\
\text { TRG2 } \\
- \\
\text { TRG3 }\end{array}$ & 180 & 6,864 & 527 & 347 \\
\hline Bekasi & $\begin{array}{l}\text { DC - } \\
\text { BKS3 } \\
- \\
\text { BKS4 } \\
- \\
\text { BKS1 }\end{array}$ & 77 & 3,602 & 114 & 37 \\
\hline Bogor & $\begin{array}{l}\text { DC - } \\
\text { BGR5 } \\
- \\
\text { BGR2 } \\
- \\
\text { BGR4 } \\
- \\
\text { BGR1 } \\
- \\
\text { BGR3 }\end{array}$ & 213 & 4,804 & 385 & 172 \\
\hline $\begin{array}{l}\text { Cikarang } \\
\text { I }\end{array}$ & $\begin{array}{l}\text { DC - } \\
\text { CKR1 } \\
- \\
\text { CKR7 } \\
- \\
\text { CKR8 } \\
- \\
\text { CKR1 } \\
0 \quad- \\
\text { CKR1 } \\
3\end{array}$ & 46 & 3,526 & 128 & 82 \\
\hline $\begin{array}{l}\text { Cikarang } \\
\text { II }\end{array}$ & $\begin{array}{l}\text { DC - } \\
\text { CKR2 } \\
- \\
\text { CKR3 } \\
- \\
\text { CKR6 }\end{array}$ & 45 & 3,683 & 168 & 123 \\
\hline
\end{tabular}

\begin{tabular}{|c|c|c|c|c|c|}
\hline Area & Trip & $\begin{array}{c}\text { Tital } \\
\text { Mileag } \\
\text { e }(\mathbf{K M})\end{array}$ & $\begin{array}{c}\text { Deliver } \\
\text { y } \\
\text { Volume } \\
\text { (KG) }\end{array}$ & $\begin{array}{c}\text { Total } \\
\text { Mileage } \\
\text { of } \\
\text { Individua } \\
\text { I } \\
\text { Shipment } \\
\text { (KM) }\end{array}$ & $\begin{array}{c}\text { Tatal } \\
\text { Saving } \\
\text { Mileag } \\
\text { e (KM) }\end{array}$ \\
\hline & $\begin{array}{l}- \\
\text { CKR4 } \\
- \\
\text { CKR5 } \\
- \\
\text { CKR1 } \\
1 \\
\end{array}$ & & & & \\
\hline Semarang & $\begin{array}{l}\text { DC - } \\
\text { SMG1 } \\
- \\
\text { SMG3 } \\
- \\
\text { SMG4 } \\
- \\
\text { SMG2 } \\
\end{array}$ & 442 & 6,656 & 1,551 & 1,109 \\
\hline Surabaya & $\begin{array}{l}\text { DC - } \\
\text { SBY3 } \\
- \\
\text { SBY2 } \\
- \\
\text { SBY1 }\end{array}$ & 729 & 4,145 & 2,205 & 1,476 \\
\hline
\end{tabular}

Based on the results of data processing with the Clarke-Wright method, six routes of Milk Run delivery method per customer area were obtained. The Cikarang area has the most number of customers. Therefore, the shipping route is divided into two to avoid a route that is too long.

Based on the predetermined route, it is known that the total mileage savings will be higher along with the distance of customer from Distribution Centre. In Table 4 , the total utilization of the distance is greatest for the Surabaya area, followed by Semarang, Tangerang, Bogor, Cikarang I and Bekasi. In line with the opinion of [12] that the effectiveness of the delivery time window method is influenced by the geographical conditions of the shipping area

However, there is an exception for the Bekasi area route, where the total distance savings produced is smaller than the Cikarang I area route even though its position is further from DC PT XYZ in the Karawang area. This is because there are more customers in the Cikarang I area (a total of 5 customers) while there are only 3 customers in the Bekasi area.

\section{CONCLUSION}

In this paper, the efficiency process of the transportation network at PT XYZ can be applied and supported by adequate system infrastructure (SAP), special characteristics of the Flavor House industry, and customer order patterns that tend to be routine. The time window delivery method could increase the efficiency of the shipping process at PT XYZ. This can be seen from the simulation results which showed that the truck 
rental cost per unit of $\mathrm{KG}$ has decreased after using the time window method. The Time Window method was more effective for routine high tonnage orders, while routine low tonnage orders could use the Milk Run method to achieve optimum truck load capacity and saving a mileage on delivery process. The effectiveness of the Milk Run method was also influenced by geographical conditions and customer distribution.

\section{REFERENCES}

[1] A. L. Guiffrida and R. Nagi, "Cost characterizations of supply chain delivery performance," Int. J. Prod. Econ., vol. 102, no. 1, pp. 22-36, 2006.

[2] M. A. Bushuev, "Delivery performance improvement in two-stage supply chain," Int. J. Prod. Econ., vol. 195, no. September 2017, pp. 6673, 2018.

[3] A. Akbalik and B. Penz, "Comparison of just-intime and time window delivery policies for a single-item capacitated lot sizing problem," Int. J. Prod. Res., vol. 49, no. 9, pp. 2567-2585, 2011.

[4] S. Chopra and P. Meindl, Supply Chain Management (Strategy, Planning, and Operation). 6th ed. s.1.:Pearson, 2016.

[5] M. A. Bushuev and A. L. Guiffrida, "Optimal position of supply chain delivery window: Concepts and general conditions," Int. J. Prod. Econ., vol. 137, no. 2, pp. 226-234, 2012.
[6] A. Meyer and B. Amberg, "Transport concept selection considering supplier milk runs - An integrated model and a case study from the automotive industry," Transp. Res. Part E Logist. Transp. Rev., vol. 113, pp. 147-169, 2018.

[7] C. K. Y. Lin, "A vehicle routing problem with pickup and delivery time windows, and coordination of transportable resources," Comput. Oper. Res., vol. 38, no. 11, pp. 1596-1609, 2011.

[8] A. S. Hanbazazah, L. Abril, M. Erkoc, and N. Shaikh, "Freight consolidation with divisible shipments, delivery time windows, and piecewise transportation costs," Eur. J. Oper. Res., no. xxxx, 2019.

[9] A. Segerstedt, "A simple heuristic for vehicle routing-A variant of Clarke and Wright's saving method," Int. J. Prod. Econ., vol. 157, no. 1, pp. 74-79, 2014.

[10] R. B. Chase, R. Shankar, and F. R. Jacobs, Operations and Supply Chain Management, 15e (SIE). McGraw-Hill Education, 2018.

[11] J. D. Wisner, K.C. Tan, and G. K. Leong, Principles of Supply Chain Management: A Balanced Approach, 3rd Edition. Cengage Learning. South-Western, 2012.

[12] A. Meyer and B. Amberg, "Transport concept selection considering supplier milk runs-an integrated model and a case study from the automotive industry," Transportation Research Part E: Logistics and Transportation Review, vol. 113, pp.

147-169,

2018. 